\title{
Urolithiasis as a complication of the surgical treatment of ulcerative colitis
}

\author{
Z. MARATKA AND J. NEDBAL \\ From the Department of Gastroenterology, Bulovka Hospital, \\ Prague, Czechoslovakia
}

EDITORIAL SYNOPSIS This paper records an increased incidence of calculi in the urinary tract in patients who have had surgical treatment with ileostomy for ulcerative colitis. It is suggested that the loss of water and sodium through the ileostomy results in a fall in urinary output and urinary sodium loss and a tendency for stones to form.

Amongst 512 patients with ulcerative colitis whom we have seen in the past 20 years we have noted the presence of urinary tract calculi in $\mathbf{1 0}$ of them. In view of the frequency of this condition such an incidence might have been expected were it not for the fact that nine of the 10 patients had been treated surgically and in these nine urinary stones formed after ileostomy or ileostomy with colectomy. In the total group of 512 patients only 74 had been subjected to surgical treatment so that the incidence of stone in this surgical group was $13 \%$. With one exception (case 9), there were no symptoms or signs of urinary stones before operation.

\section{CASE REPORTS}

The series is summarized in Table I.

CASE 1 A 57-year-old woman had suffered from ulcerative colitis since 1945 and underwent ileostomy and proctocolectomy in 1954. Four years later she suffered from bilateral renal colic and renal and ureteric calculi were demonstrated on both sides. A right pyelolithotomy in 1961 did not prevent further renal infection and pyelonephritis. The urine contained protein, red blood cells, and urate crystals, and was acid in reaction.

CASE 2 A 43-year-old woman suffered from a severe attack of colitis which had been treated by caecostomy in

TABLE I

SUMMARY OF CLINICAL FINDINGS

\begin{tabular}{|c|c|c|c|c|c|}
\hline Case No. & Age & $\operatorname{Sex}$ & Operation & First Symptoms of Urolithiasis & Subsequent Course and Treatment \\
\hline 1 & 57 & $\mathbf{F}$ & $\begin{array}{l}\text { Sept. } 1954 \text {, ileostomy } \\
\text { Dec. } 1954 \text {, proctocolectomy }\end{array}$ & $\begin{array}{l}\text { April 1958, } \\
\text { Renal colic }\end{array}$ & $\begin{array}{l}\text { Pyelolithotomy } \\
\text { Pyelonephritis, } \\
\text { well }\end{array}$ \\
\hline 2 & 43 & $\mathbf{F}$ & $\begin{array}{l}\text { March } 1958 \text {, caecostomy } \\
\text { Oct. } 1958 \text {, ileostomy } \\
\text { May } 1959 \text {, colectomy } \\
\text { June } 1961 \text {, ileorectal anastomosis }\end{array}$ & $\begin{array}{l}\text { Feb. } 1960 \text {, accidental } x \text {-ray } \\
\text { finding }\end{array}$ & Nephrectomy, well \\
\hline 4 & 40 & $\mathbf{M}$ & $\begin{array}{l}\text { Feb. } 1961 \text {, ileostomy and colectomy } \\
\text { Aug. } 1962 \text {, proctectomy }\end{array}$ & $\begin{array}{l}\text { Sept. } 1962 \text {, renal colic and } \\
\text { haematuria }\end{array}$ & Well \\
\hline 5 & 33 & $\mathbf{F}$ & $\begin{array}{l}\text { Oct. } 1955 \text {, ileostomy and colectomy } \\
\text { March } 1957 \text {, proctectomy }\end{array}$ & $\begin{array}{l}\text { Nov. } 1961, \text { microscopic } \\
\text { haematuria }\end{array}$ & $\begin{array}{l}\text { Pyelonephritis and uraemia, } \\
\text { died }\end{array}$ \\
\hline 6 & 46 & $\mathbf{F}$ & $\begin{array}{l}\text { Oct. } 1962 \text {, ileostomy } \\
\text { March 1963, colectomy and ileorectal } \\
\text { anastomosis }\end{array}$ & Jan. 1963, renal colic & Well \\
\hline 8 & 29 & $\mathrm{~F}$ & $\begin{array}{l}\text { March } 1961 \text {, ileostomy } \\
\text { June } 1961 \text {, colectomy } \\
\text { Feb. 1962, proctectomy }\end{array}$ & $\begin{array}{l}\text { June, } 1961 \text {, renal colic and } \\
\text { haematuria }\end{array}$ & Well \\
\hline 9 & 18 & $\mathbf{M}$ & $\begin{array}{l}\text { Feb. } 1961 \text {, colectomy and } \\
\text { ileorectal anastomosis }\end{array}$ & Feb. 1961, passed urate stone & Well \\
\hline
\end{tabular}


1958. Two years later a calculus was noted radiologically in the right renal pelvis during a barium enema examination. The urine then contained red blood cells, white cells, and oxalate crystals. Ileostomy and subtotal colectomy had been performed and because of symptoms of persistent urinary infection a right nephrectomy was performed in 1960. The kidney showed evidence of chronic pyelitis and focal nephritis. Ileo-rectal anastomosis has since been performed and the patient remains well with no urinary symptoms.

CASE 3 A 19-year-old woman has suffered from colitis since 1958, and, in 1960, because of severe symptoms, ileostomy and later subtotal colectomy were performed. In the following year she suffered from left renal colic with haematuria and a stone was passed. On subsequent urography only dilatation of the left ureter was seen, though the urine showed many red blood cells and oxalate crystals. Since ileorectal anastomosis the patient has been well and the urine is normal.

CASE 4 A 40-year-old man first suffered from ulcerative colitis in 1959 and underwent ileostomy and subtotal colectomy two years later, followed by removal of the rectal stump. In 1962 he first suffered from left renal colic and haematuria. A stone was passed spontaneously and subsequent renal infection was cured by antibiotics. The urine contained urates and phosphates.

CASE 5 A 33-year-old woman had a subtotal colectomy and ileostomy performed for acute ulcerative colitis with later removal of the rectal stump. On examination six years after the operation there was microscopic haematuria and urography showed a stone in a hydronephrotic right kidney. There was also dilatation of the right ureter. Progressive deterioration in renal function occurred over the following year with infection of the left kidney, and the patient died from uraemia.

CASE 6 A 46-year-old woman had suffered from ulceraative colitis since 1956 and, following an acute exacerbation, an ileostomy was performed. In 1963, three months after the operation, she suffered from right renal colic which recurred. One month later urography showed no renal function on the right side. No further attacks of renal colic have occurred since March 1963 and ileorectal anastomosis has been performed.

CASE 7 A 52-year-old man had suffered from ulcerative colitis since 1953 and in 1961 had a relapse which eventually necessitated ileostomy. Following this operation the patient was much improved, though he had several attacks of renal colic with the passage of oxalate stones. In march 1963 proctocolectomy was performed and since this time other attacks of renal colic have occurred.

CASE 8 A 29-year-old woman developed severe ulcerative colitis in February 1961 for which an ileostomy was performed followed three months later by colectomy. The operation was followed by typical renal colic with haematuria. Since resection of the rectal stump in 1962 there have been no further renal symptoms.
CASE 9 An 18-year-old man developed severe ulcerative colitis in 1960. Despite conservative therapy operation was considered necessary. Ten days before the operation the patient passed some urate gravel which recurred post-operatively.

\section{DISCUSSION}

Clinically urolithiasis in these patients presented as renal colic in six, with the passage of urinary stones in one, as microscopic haematuria in one, and as an accidental finding on barium enema examination in another.

Urolithiasis is of frequent occurrence in Czechoslovakia (Mates and Kř́žek, 1958), and, judging from figures from the United States (Boyce, Garvey and, Stawcutter, 1956), where the incidence is $1: 1,000$ of the population, one or two cases might have been expected in out-patients with colitis treated conservatively. On the other hand, eight patients with urolithiasis in a group of 74 treated surgically shows a significant increase. Calculi were available for analysis in two patients only (cases 7 and 8) and these were oxalate and urate stones respectively. In other patients the urinary sediment showed crystals of oxalate urate and phosphate.

Amongst factors possibly concerned in the formation of urinary stones in patients with ulcerative colitis are dehydration, electrolyte depletion, changes in urinary $p \mathrm{H}$, bacteruria and urinary infection, bed rest, and corticosteroid therapy. Disturbances of water and electrolyte balance are common, perhaps particularly so after ileostomy (Brooke, 1956; Fowler, Cooke, Brooke, and Cox, 1959; Lambling, Bernier, Lormeau, Loizeau, and Lequintrec, 1961). Surgical treatment, though arresting alimentary blood loss, does not prevent the dangers of water and salt depletion (MacFadyen, Akre, Duncan, Flesch, and Mauser, 1954). The losses following ileostomy are greatest in the first week when the daily volume may reach $1,500 \mathrm{ml}$. and sodium concentration $120 \mathrm{mEq} . / 1$. (Smiddy, Gregory, Smith, and Goligher, 1960). The loss of potassium may also be two to three times greater than in normal faeces. Balance studies in patients who have undergone proctocolectomy with ileostomy for ulcerative colitis have shown that electrolyte and, particularly sodium, loss continues so that urinary volume and sodium loss decrease (Gallagher Harrison, and Skyring, 1962).

The renal adjustments to continuing electrolyte loss may be responsible for formation of calculus (Klika, 1957). The solubility of calcium salts depends on the concentration of other electrolytes. Thus, the solubility of calcium oxalate is increased by magnesium and particularly by citrate which 
TABLE II

SODIUM CONCENTRATIONS IN PLASMA, URINE, AND STOOLS IN PATIENTS WITH ULCERATIVE COLITIS AND UROLITHIASIS

\begin{tabular}{|c|c|c|c|c|c|}
\hline Case No. & Date & Plasma (Na mEq./1.) & Urine (Na mEq./1.) & Stool (Na mEq./l.) & Note \\
\hline \multirow[t]{2}{*}{1} & May 1960 & 137 & 62 & $108\}$ & \multirow{4}{*}{$\begin{array}{l}\text { Six years after ileostomy and } \\
\text { proctocolectomy } \\
\text { One year after ileostomy and } \\
\text { proctocolectomy }\end{array}$} \\
\hline & June 1960 & 148 & 92 & $138\}$ & \\
\hline 2 & April 1960 & 136 & 90 & $82\}$ & \\
\hline \multirow{4}{*}{3} & Jan. 1960 & & $\begin{array}{r}96 \\
148\end{array}$ & 108\{ & \\
\hline & $\begin{array}{l}\text { Jan. } 1960 \\
\text { Feb. } 1960\end{array}$ & $\begin{array}{l}127 \\
151\end{array}$ & $\begin{array}{l}148 \\
156\end{array}$ & $z$ & Before ileostomy \\
\hline & April 1963 & - & 97 & $34\}$ & \multirow{2}{*}{$\begin{array}{l}18 \text { months after ileorectal } \\
\text { anastomosis }\end{array}$} \\
\hline & & & 150 & 53 & \\
\hline \multirow[t]{2}{*}{4} & Feb. 1961 & $\begin{array}{l}119 \\
128\end{array}$ & $<\begin{array}{l}11 \\
22\end{array}$ & $\left.\begin{array}{l}130 \\
150\end{array}\right\}$ & Immediately after ileostomy \\
\hline & Aug. 1961 & 128 & 176 & - & \multirow{2}{*}{$\begin{array}{l}\text { Six months later } \\
\text { Seven years after proctocolectomy }\end{array}$} \\
\hline 5 & Nov. 1962 & 120 & 24 & 180 & \\
\hline 6 & April 1963 & 111 & $<11$ & $\left.\begin{array}{l}109 \\
124\end{array}\right\}$ & Immediately after ileostomy \\
\hline 7 & April 1963 & 114 & $\begin{array}{l}30 \\
41\end{array}$ & $\begin{array}{l}103 \\
124\end{array}$ & One month after proctocolectomy \\
\hline \multirow[t]{4}{*}{9} & Feb. 1961 & 135 & $\begin{array}{l}41 \\
35\end{array}$ & $\begin{array}{c}124 \\
87\end{array}$ & \multirow{2}{*}{ Before operation (calculi present) } \\
\hline & Feb. 1961 & 128 & $<11$ & $222\}$ & \\
\hline & March 1961 & 133 & 35 & 135 & $\begin{array}{l}\text { Immediately after colectomy and } \\
\text { ileorectal anastomosis }\end{array}$ \\
\hline & May 1963 & - & $\begin{array}{l}124 \\
162\end{array}$ & $54\}$ & Two years later \\
\hline
\end{tabular}

forms a complex with calcium. The presence of sodium, potassium chloride, and sulphate and citrate increases the solubility of calcium salts in the urine (Vermeulen, Lyon, and Miller, 1958). The organic matrix of calculi contains mucopolysaccharides that accumulate in the urine probably as a sequel of impaired renal tubular absorption. The $p \mathrm{H}$ of the urine may be a further factor of importance; a low urinary $p \mathrm{H}$ resulting from increased loss of alkali in the stools promotes the formation of urate calculi. Contrariwise, the onset of urinary infection and a resultant alkaline urine may be a factor in the formation of phosphate and carbonate calculi. Bed rest is a further factor which must be considered.

Surgical treatment aids the formation of renal stones by lowering the urinary output and increasing the reabsorption of sodium by the renal tubules. Gallagher and his colleagues (1962) have shown that the urinary volume decreases, as does the urinary sodium excretion following surgery. In Table II the urinary plasma and stool sodium in the patients with urolithiasis is shown, and it can be seen that post-operatively the urinary sodium level is usually low (normal 80 to $110 \mathrm{mEq}$./1.) particularly in the early post-operative phase when it may fall to $<11 \mathrm{mEq}$./1. (cases 4, 6, and 9). Conversely the stool sodium concentration in the intestinal contents was high. It is noteworthy that in case 9 this high stool/urine sodium ratio was present before the operation when he had already developed urolithiasis. These alterations in sodium excretion may still be present in patients with long-established ileostomies, perhaps accounting for the relapses and chronicity of the urolithiasis in some cases.
So far we have not seen urinary stone formation following ileo-rectal anastomosis and in three out of four patients in whom this operation has been performed no further signs of urinary stone formation or infection have occurred. The urinary sodium concentration in the urine of these patients was normal. In Table II it can be seen that the normal sodium excretion pattern is inverted in the urine and stools after ileo-rectal anastomosis, but this is only found in the early post-operative period. Presumably preservation of the rectal stump and anal sphincter leads to sodium reabsorption, but it will be necessary to examine further patients in order to see whether this is so and whether ileo-rectal anastomosis will minimize the dangers of urinary stone formation. Certainly it seems that the patient with colitis is not only liable to depletion of electrolytes in the acute stage of the disease and immediately after surgery, but also there is a further and permanent risk after ileostomy of similar depletion and formation of stones in the renal tract.

After an ileostomy it is therefore important to ensure an adequate fluid and electrolyte intake, particularly in view of the losses due to fever and sweating as well as losses via the ileostomy, otherwise there is a risk of urinary stone formation, urinary infection, and possibly permanent renal damage.

\section{SUMMARY}

Of 74 surgically treated patients with ulcerative colitis nine developed calculi of the urinary tract. This complication occurred in eight of the nine patients at varying periods after the operations of 
ileostomy and colectomy. The symptoms included renal colic and the passage of calculi in seven and in two patients the condition was discovered accidentally. Progressive renal change and urinary infection occurred in three of the nine patients. In 438 patients with colitis treated conservatively there is only one known case of urinary calculus. It is thought that the loss of water and sodium via the ileostomy results in a fall in urinary output and urinary sodium loss, and a tendency to stone formation. The danger period is the first week after ileostomy but the lowered urinary sodium output continues so that the risk is a permanent one. Changes in urinary phosphate and urinary infections and bed rest are also possible contributory factors. Ileorectal anastomosis, unlike ileostomy, is not followed by a permanent lowering of urinary sodium excretion and urinary stones do not form.

We acknowledge the helpful assistance of Dr. D. Chytilova who performed the biochemical studies. The patients treated surgically were under the care of Professor Knobloch, Professor Niederle, and Dr. Paces to whom we are also grateful.

\section{ADDENDUM}

Since this paper was submitted to Gut we came upon another paper on the same subject (Deren, Porush, Lewitt, and Khilnani, 1962).

\section{REFERENCES}

Boyce, W. H., Garvey, F. K., and Stawcutter, H. E. (1956). Incidence of urinary calculi among patients in general hospitals 1948 to 1952. J. Amer. med. Ass., 161, 1437-1442.

Brooke, B. N. (1956). Discussion on ileostomy. Proc. roy. Soc. Med., 49. 949-952.

Deren, J. J., Porush, J. G., Lewitt, M. F., and Khilnani, M. T. (1962) Nephrolithiasis as a complication of ulcerative colitis and regional enteritis. Ann. intern. Med., 56, 843-853.

Fowler, D. I., Cooke, W. T., Brooke, B. N., and Cox, E. V. (1959) Ileostomy and electrolyte excretion. Amer. J. dig. Dis., 4 710-720.

Gallagher, N. D., Harrison, D. D., and Skyring, A, P. (1962). Fluid and electrolyte disturbances in patients with long-established ileostomies. Gut, 3, 219-223.

Klika, M. (1957). Profylaxe urolithiasy. Cas. Lék. čes., 96, 445-451.

Lambling, A., Bernier, J. J., Lormeau, G., Loizeau, E., and Lequintrec Y. (1961). Les hyperchlorémies après iléostomies définitives. Difficultés du traitement par le bicarbonate de soude. Arch. Mal. Appar, dig., 50, 1305-1315.

MacFadyen, D. A., Akre, O. H., Duncan, J., Flesch, F., and Mauser, M. (1954). Electrolyte metabolism in ulcerative colitis patients before and after surgery. Gastroenterology, 27, 544-564.

Mates, J., and Křižek, V. (1958). Urolithiasa. Stat. zdrav. nakl., Prague.

Smiddy, F. G., Gregory, S. D., Smith, I. B., and Goligher, J. C. (1960). Faecal loss of fluid, electrolytes, and nitrogen in colitis before and after ileostomy. Lancet, 1, 14-19.

Vermeulen, C. W., Lyon, E. S., and Miller, G. H. (1958). Calcium phosphate solubility in urine as measured by a precipitation test: experimental urolithiasis, XIII. J. Urol. (Baltimore), 79, 596. 